\title{
A PRESENÇA INDÍGENA NAS CAPELAS DA CAPITANIA DE SÃO VICENTE (SÉCULO XVII)
}

GLÓRIA KOK ${ }^{1}$

UNICAMP

RESUMO: Este artigo tem o objetivo de examinar as múltiplas ações indígenas no âmbito das capelas da Capitania de São Vicente durante o século XVII. Nesse contexto, as capelas, administradas por ordens religiosas e por particulares, concentraram centenas de índios trazidos do sertão e, não raro, preservaram práticas, saberes, identidades e tradições culturais indígenas.

PALAVRAS-CHAVE: índios; capelas; capitania de São Vicente.

ABSTRACT: The goal of this article is to examine the several activities of the Indians in the field of the chapels in the Capitany of São Vicente, during the seventeenth-century. In this context, these chapels, administrated by religious orders as well by landlords, had concentrated hundreds of Indians brought from the "sertão" and, eventually, preserved indigenous practices, knowledges, identities and cultural traditions.

KEYWORDS: Indians; chapels; capitany of São Vicente.

\section{Introdução}

[...] há de reverenciar e defender especialmente as capelinhas toscas, as velhices dum tempo de luta e os restos de luxo esburacado que o acaso se esqueceu de destruir.

Mário de Andrade (1965, p. 81).

\footnotetext{
${ }^{1}$ Formada em Filosofia na Universidade de São Paulo, Glória Kok é mestre e doutora em História Social pela Universidade de São Paulo. É autora de Os vivos e os mortos na América portuguesa: da antropofagia à água do batismo (2001), O Sertão Itinerante. Expedições da Capitania de São Paulo no século XVIII (2004), entre outras publicações. Membro do Centro de Pesquisa em Etnologia Indígena (CPEI), realiza uma pesquisa de pós-doutorado sobre os índios das capelas coloniais de São Paulo junto ao Departamento de Antropologia da UNICAMP. E-mail: kokmartins@ uol.com.br .
} 


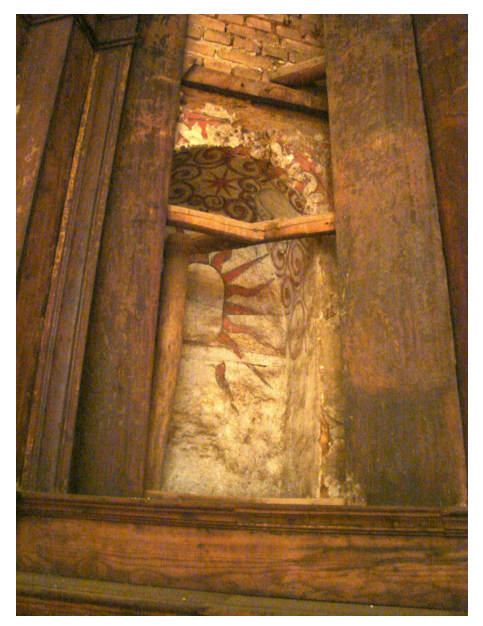

Figura 1: Pintura parietal do século XVII, feita provavelmente pelos índios, descoberta atrás do altar lateral em 2004. Capela de São Miguel. Foto de Glória Kok.

Este artigo enfoca as ações indígenas no âmbito das capelas erguidas na Capitania de São Vicente, sobretudo no século XVII, administradas tanto por ordens religiosas como por proprietários particulares. Espaços de conquista do império ultramarino, as capelas concentraram centenas ${ }^{2}$ de índios trazidos do sertão. As primeiras capelas do planalto, sob a responsabilidade dos jesuítas, contribuíram para a formação de uma cultura ibero-ameríndia que conjugou acervos culturais dos jesuítas, do mundo ibérico e dos grupos indígenas. Aos índios aldeados ou cristãos, somaram-se os chamados "índios encapelados", os quais viviam em torno das capelas erguidas nas propriedades particulares. Trata-se, portanto, de uma outra categoria do índio colonial, indicativa de uma forma de vínculo dos nativos com os adventícios. Conforme afirma a historiadora Karen Spalding (1972), a história da sociedade colonial não é apenas a do transplante da sociedade europeia para o Novo Mundo, mas, sobretudo, é a história do desenvolvimento de novas tradições culturais e de interações entre diversos grupos sociais (SPALDING, 1972, p. 47-76). Os índios das

\footnotetext{
2 "Quando se achava no Collegio, sahia pela Villa a doutrinar o Gentio, de que naquelles tempos abundava S. Paulo; porque como a sahida ordinária dos seus moradores era ao Certão, e delle tiravão grandes levas, era tal a abundancia, que contavão alguns nas suas fazendas quatrocentos, outros quinhentos, e algum chegou a contar mais de novecentos", testemunha o padre Belchior Pontes (FONSECA, 1752, p.113).
} 
DOSSIÊ: FONTES E PROBLEMAS COLONIAIS, LEITURAS E ANÁLISES ATUAIS: TEMAS DA CULTURA SUL-AMERÍNDIA NO CONTEXTO COLONIAL

capelas exerceram múltiplos papéis, inclusive nos movimentos de expansão paulista em busca de índios e de ouro em direção ao Vale do Paraíba e às regiões de Minas Gerais (1698), Cuiabá (1718) e Goiás (1725). Nesse complexo panorama, as capelas, não raro, foram guardiãs de ações, práticas, saberes e identidades indígenas.

\section{As primeiras capelas}

Na ocasião da fundação do Colégio de São Paulo pelos jesuítas, a 25 de janeiro de 1554, a construção improvisada que se ergueu na confluência do rio Tamanduateí e do ribeiro Anhembi não passava de "uma pobre casinha feita de barro e paus, coberta de palha, tendo quatorze passos de comprimento e apenas dez de largura" (ANCHIETA, 1988, p. 53). Segundo Anchieta, o padre Afonso Brás ajudou a construir a igreja e a fazer as casas de taipa, "com incomensurável trabalho" para todos os índios catecúmenos (LEITE, 1953, p. 135). Nesses primeiros tempos, a participação dos índios aliados assegurou a implantação do projeto missionário dos jesuítas, bem como a reconfiguração espacial da nova ordem.

O cacique da aldeia de Inhapuambuçu, batizado com o nome de Martim Afonso Tibiriçá, deslocou sua aldeia para as proximidades do Colégio no intuito de adensar o núcleo e selar aliança com os portugueses. "Junto da Vila", escreve Anchieta, "ao princípio havia doze aldeias, não muito grandes, de índios, a uma, duas, e três léguas por água e por terra, as quais eram continuamente visitadas pelos padres e se ganhavam muitas almas pelo batismo e outros sacramentos" (ANCHIETA apud TAUNAY, 2003, p. 236).

Da vila de São Paulo, centro irradiador da conquista espiritual, formaram-se as primeiras aldeias coloniais, sob a administração dos jesuítas e o controle dos agentes do governo (CAMARGO, 1952, p. 203). Muitas delas tiveram duração efêmera no século XVI: Mairanhaia, Jeribatiba, Ambuaçava ou Embuaçava e Maniçoba, enquanto outras foram fundamentais no processo de colonização do planalto: São 
DOSSIÊ: FONTES E PROBLEMAS COLONIAIS, LEITURAS E ANÁLISES ATUAIS: TEMAS DA CULTURA SUL-AMERÍNDIA NO CONTEXTO COLONIAL

Miguel, Conceição de Nossa Senhora dos Pinheiros, Itaquaquecetuba e Ibirapuera, de 1560. As primeiras aldeias cristãs, fundadas sobre aldeias tupiniquins pré-cabralinas, abrigavam os grupos indígenas que habitavam na região, principalmente os Tupiniquim e os Guaianá. (MONTEIRO, 1994, p. 43) ${ }^{3}$. Esclarece Frei Gaspar Madre de Deus que, à medida que os portugueses se apropriavam das terras indígenas, os índios se transferiam para duas aldeias: a de Pinheiros e a de São Miguel (MADRE DE DEUS, 1975, p. 125). "Entre ambas terão 1.000 pessoas, e há nesta terra muito bom aparelho para conversão por haver ainda grande número de gentio não muito longe" (ANCHIETA, [1585], 1988, p. 433). Anchieta referia-se à posição estratégica de São Paulo para conquistar os Carijó, a fim de incorporá-los ao "viveiro de catecúmenos". A aldeia de Nossa Senhora da Conceição dos Guarulhos foi criada em 1580 para servir de abrigo aos Maromins (Guarulhos), Guaianás e Ibirabaquiyaras (prováveis Kayapó do Sul).

Os índios cristãos das aldeias de Conceição de Nossa Senhora dos Pinheiros e de S. Miguel, pontos estratégicos de defesa da vila, receberam, em 1580, as datas de sesmarias de seis léguas em quadra, medida padrão da época, das mãos do capitão Jerônimo Leitão, uma liderança política de grande destaque responsável por conceder licenças para as entradas do sertão, encaminhar os índios apresados, organizar os guerreiros, comandar as guerras de conquista contra os índios do sertão e da vila, capturar os índios "contrários", enviar esforços para outras capitanias e proteger a Capitania de São Vicente. As terras das aldeias foram consideradas propriedades coletivas que pertenciam aos residentes das aldeias, a serem exploradas apenas pelos índios da vila (MONTEIRO, 1985, p. 48), buscando incentivar o trabalho agrícola e fixar os catecúmenos ao solo. As aldeias coloniais transformavam o índio em cristão, vassalo do Rei e mão de obra para a Coroa, os colonos e os jesuítas, e ainda cumpriam um papel importante na "ressocialização

\footnotetext{
${ }^{3}$ Dos grupos indígenas que circulavam na região, os adventícios identificaram os que falavam a língua tupi-guarani: os Tupiniquim, Tupinambá, Tobajara, Tamoio, Tememinó, povos Tupi, e os "de língua travada", os Guaianá, povo Jê, obedecendo a uma classificação que segue o binômio Tupi-Tapuia (MONTEIRO, 1994, p. 20).
} 
DOSSIÊ: FONTES E PROBLEMAS COLONIAIS, LEITURAS E ANÁLISES ATUAIS: TEMAS DA CULTURA SUL-AMERÍNDIA NO CONTEXTO COLONIAL

dos povos indígenas e na recriação de suas identidades" (ALMEIDA, 2001, p. 26).

Os índios aldeados trabalhavam em roças, fazendas, formavam tropas de combate, transportavam mercadorias, defendiam as fronteiras e a vila, construíam casas, pontes, fortalezas, capelas, abriam caminhos, remavam e lutavam contra os inimigos estrangeiros ou nativos. $\mathrm{Na}$ expressão de Pasquale Petrone, eram "motores animados aplicados a toda a sorte de trabalhos" (PETRONE, 1995, p. 213). As estratégias de guerra e de defesa dos moradores estavam no cerne das preocupações dos camaristas de São Paulo. Alianças dinâmicas e versáteis entre diversos grupos indígenas da vila e do sertão promoviam revoltas, mortes e guerras. Em 1562, a documentação da Câmara identifica alguns autores implicados nos conflitos: os Tupiniquim de Ururaí, de Pinheiros e do sertão, os Carijó do Sul, que buscavam mulheres brancas (DEPARTAMENTO DO ARQUIVO DO ESTADO, 1913, p. 22), os Tamoio do litoral do Rio de Janeiro e grupos "contrários" que se "alevantaram" contra os adventícios, como os Guanonimi ou Maromimi (Guarulhos), os das "nações hybiribabacas", provavelmente os Kayapó, e os Guaianá. Devido à "terra em desordem" e "à gente desinquieta", os oficiais das Câmaras de São Vicente declararam guerra. Dois anos depois, organizavam a partilha das "peças" capturadas.

Em 1590, a aliança dos índios do sertão com os índios aldeados da vila gerou uma revolta indígena de grande proporção. Um dos catecúmenos entrou na capela da aldeia de Pinheiros e quebrou a imagem de Nossa Senhora dos Pinheiros. Reparada a capela e restaurada a imagem, o local se tornou um grande centro de romaria para o culto de Nossa Senhora dos Pinheiros (PETRONE, 1995, p. 221). A 8 de setembro de 1608, a Câmara deixou de se reunir, porque "não haveria gente pronta por respeito da romaria da Nossa Senhora dos Pinheiros" (AMARAL, 1969, p. 23). Muitas mulheres que viviam na vila de São Paulo nutriam devoção à Virgem. Ana Alvarenga, mulher de Gaspar de Godoi Moreira, deixa em testamento de $1^{\circ}$ de abril de 1648 "um manto de tafetá" azul a Nossa Senhora dos Pinheiros. Maria de Lara, filha de Lourenço Castanho Taques, o velho, deixa de esmola outro 
DOSSIÊ: FONTES E PROBLEMAS COLONIAIS, LEITURAS E ANÁLISES ATUAIS: TEMAS DA CULTURA SUL-AMERÍNDIA NO CONTEXTO COLONIAL

manto "de chamalote encarnado, arrendado de renda negra" (AMARAL, 1969, p. 24-25).

Em 1592, os oficiais da Câmara informam que os índios da aldeia de São Miguel e demais aldeias estavam "arruinados" e pediam aos juízes, vereadores, vigário e escrivão da vila de São Paulo que fossem até a aldeia para "tirar devassa contra todos aquelles q forão em amotinarem os ditos índios" e que, no dia de São Miguel, se "querião levãtar contrários" (ACTAS, 1914, p. 449). Os índios de São Miguel articularam o pedido de devassa diante das autoridades coloniais para que investigassem os responsáveis pelas revoltas dos índios aldeados. Os conflitos entre os índios cristãos, os índios do sertão, os jesuítas e os colonos foram constantes na vila de São Paulo. Para diminuir a força dos índios aldeados, a Câmara passou a nomear capitães severos (BOMTEMPI, 1970, p. 48), ao mesmo tempo em que a necessidade de terras para o gado e a lavoura levou à progressiva espoliação das terras das aldeias dos índios por brancos e mamelucos.

No final do século XVI, portanto, a drástica redução da população tupi que vivia no planalto - vitimada por epidemias, guerras e apresamentos - gerou a diversificação da composição étnica. No inventário do sapateiro Damião Simões, de 1578, considerado o mais antigo da vila, é notável a relevância dos escravos índios na economia. Os seus bens materiais reduziam-se a algumas peças de algodão, um tinteiro, botas de porco, canos de sapato de mulher, restos de couro e bacias de estanho. Homem de parcos recursos, contava, entretanto, com quatro escravos tamoios para Ihe garantir a faina diária, sendo um moço "dos novos", duas mocinhas e uma velha, capturados, provavelmente, na guerra movida por Jerônimo Leitão (KOK, 2004, p. 29). João do Prado, cujo inventário data de 1597, possuía dez peças, entre as quais mencionaram um Tamoio de nome Roque, três negras do gentio da terra e duas moças Carijó (DEPARTAMENTO DO ARQUIVO DO ESTADO, 1920, p. 81). 
DOSSIÊ: FONTES E PROBLEMAS COLONIAIS, LEITURAS E ANÁLISES ATUAIS: TEMAS DA CULTURA SUL-AMERÍNDIA NO CONTEXTO COLONIAL

\section{Artífices indígenas na formação de uma cultura ibero-americana}

Durante a União Ibérica, de 1580 a 1640, o afrouxamento das fronteiras incentivou índios, espanhóis e mestiços a se deslocarem da América espanhola para a vila de São Paulo4. Segundo Rafael Ruiz,

em 1610 foram-se mais de 3.000 índios, e em 1612, conforme nos conta a carta de Bartolomé Torales ao governador do Rio da Prata, treze caciques e mais de novecentos índios foram-se seguindo o paulista Sebastião Preto, 'que los llebo com puras dádivas' (RUIZ, 2004, p. 74).

Aos deslocamentos voluntários somaram-se, entre 1628 e 1641, os ataques paulistas às missões jesuíticas espanholas do Guairá, Tape e Itatim, que capturaram um contingente de 33.000 a 55.000 índios, estimado pelo jesuíta Ruiz de Montoya (apud MONTEIRO, 1994, p. 74). Como consequência, as cidades de Villa Rica, Ciudad Real e Jerez se despovoaram, enquanto os Guarani, muitos deles versados em ofícios, passaram a compor a maior parte da população indígena da vila de São Paulo, seguidos, em menor escala, pelos Guarulho, Guaná e Kayapó. A presença Guarani deixou suas marcas na formação de uma cultura ibero-americana nas capelas de São Paulo durante o século XVII, como veremos através de alguns exemplos.

\footnotetext{
${ }^{4}$ Para aprofundar o tema das influências dos espanhóis na vila de São Paulo, ver Amaral (1983).
} 


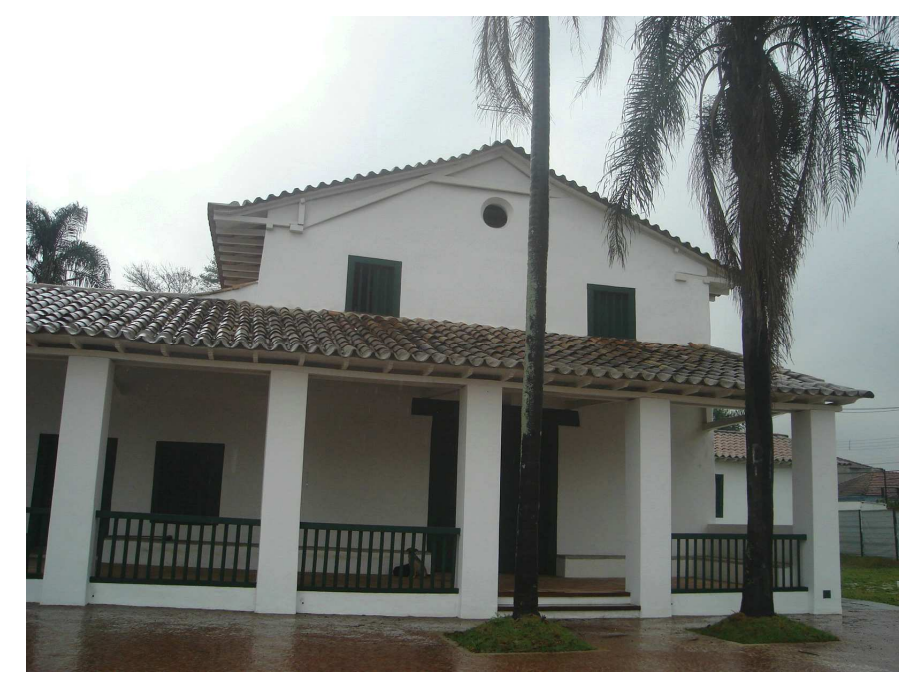

Figura 2: Capela de São Miguel. São Paulo. Fotografia de Glória Kok.

A capela de São Miguel foi fundada numa colina sobre a várzea do Tietê, nas antigas terras de Ururaí, onde se assentava uma das aldeias dos índios tupiniquin, cujo chefe era Piquerobi, irmão de Tibiriçá, em 1560. Conforme a inscrição gravada na verga da porta principal, foi concluída uma reforma em 18 de julho de 1622, quando a maior parte dos moradores era Carijó. Em troca das obras de ampliação da capela, o carpinteiro Fernão Munhoz recebeu muitas braças de terras, que pertenciam originalmente aos índios, em escritura passada pelo próprio padre, capitão e administrador da aldeia. Um corpo fletido - posição característica de muitos enterramentos indígenas - foi desenterrado da sacristia ao lado de retalhos de tecido de trançado rústico e contas de colar, o que revela o status alcançado por alguns índios da aldeia, possivelmente uma liderança indígena.

Trata-se de um dos poucos exemplares remanescentes da arquitetura religiosa brasileira que conserva integralmente os alpendres em formato de "L", uma solução tradicional europeia, que, conforme observou Luiz Saia, seguiu o modelo de igreja alpendrada da província de Salamanca, na Espanha (SAIA, 1939, p. 240). Outra função do alpendre apontada pelo arquiteto era possibilitar o acesso dos escravos à porta da capela.

Os trabalhos artísticos da Capela de São Miguel Arcanjo surpreendem pela qualidade das obras e pela a originalidade, os quais, 
DOSSIÊ: FONTES E PROBLEMAS COLONIAIS, LEITURAS E ANÁLISES ATUAIS: TEMAS DA CULTURA SUL-AMERÍNDIA NO CONTEXTO COLONIAL

provavelmente, resultaram de uma combinação fértil entre os conhecimentos transmitidos pelos jesuítas baseados em experiências vividas em outros continentes e os múltiplos acervos culturais indígenas. Renata Martins 5 , ao analisar o "encontro" das tradições culturais dos indígenas e dos jesuítas nas missões do Grão-Pará, observa que, afora a importância das artes visuais para a afirmação da fé católica, amplamente utilizada pelos jesuítas nos quatro continentes, Belém (1616) tornou-se um centro irradiador de modelos e técnicas de arte e arquitetura que, das oficinas, se difundiam pela rede de missões da Amazônia.

Acreditamos que as obras produzidas nas Oficinas de Belém, possuem aquilo que para nós melhor representa a herança artística dos jesuítas e dos índios nas missões do Grão-Pará: elementos 'da terra', elementos 'do reino', em uma 'receita' muitas vezes 'indecifrável', e por este mesmo motivo, valiosa [...] (MARTINS, 2009, p. 236).

As pinturas do forro apresentam motivos similares aos das capelas de Carapicuiba e de São Roque. Tais motivos, de acordo com estudo de Renata Martins, derivam de "brutescos" (MARTINS, 2009, p. 379). Segundo Aracy Amaral, as pinturas, de um maneirismo tardio, foram inspiradas nas pinturas da América Espanhola e da Península Ibérica (AMARAL, 1983, p. 82).

\footnotetext{
${ }^{5}$ Agradeço a Luisa T. Wittman a indicação do belo trabalho realizado por Renata Maria de Almeida Martins (2009).
} 
DOSSIÊ: FONTES E PROBLEMAS COLONIAIS, LEITURAS E ANÁLISES ATUAIS: TEMAS DA CULTURA SUL-AMERÍNDIA NO CONTEXTO COLONIAL

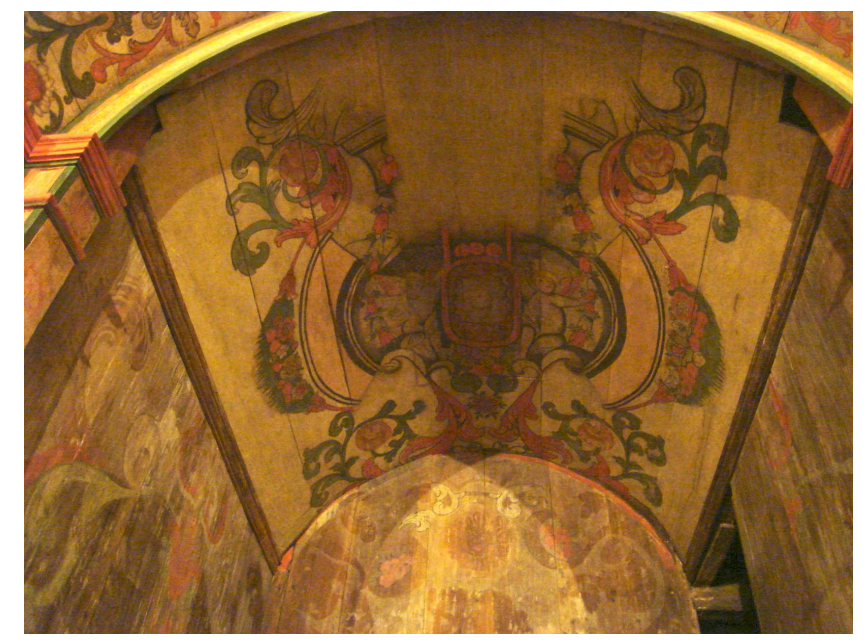

Figura 3: Pintura no teto da capela lateral, com motivos florais e arabescos. Foto de Glória Kok.

Ao lado desse padrão dos jesuítas, foi encontrada, na ocasião de uma das reformas, em 2004, uma pintura parietal do século XVII feita pelos indígenas atrás do altar lateral. Os motivos e as cores sugerem padrões indígenas, provavelmente Guarani. Apesar dos "pintores" indígenas terem sido orientados para copiar os modelos europeus, as pinturas expressavam também a recriação das tradições culturais ameríndias.

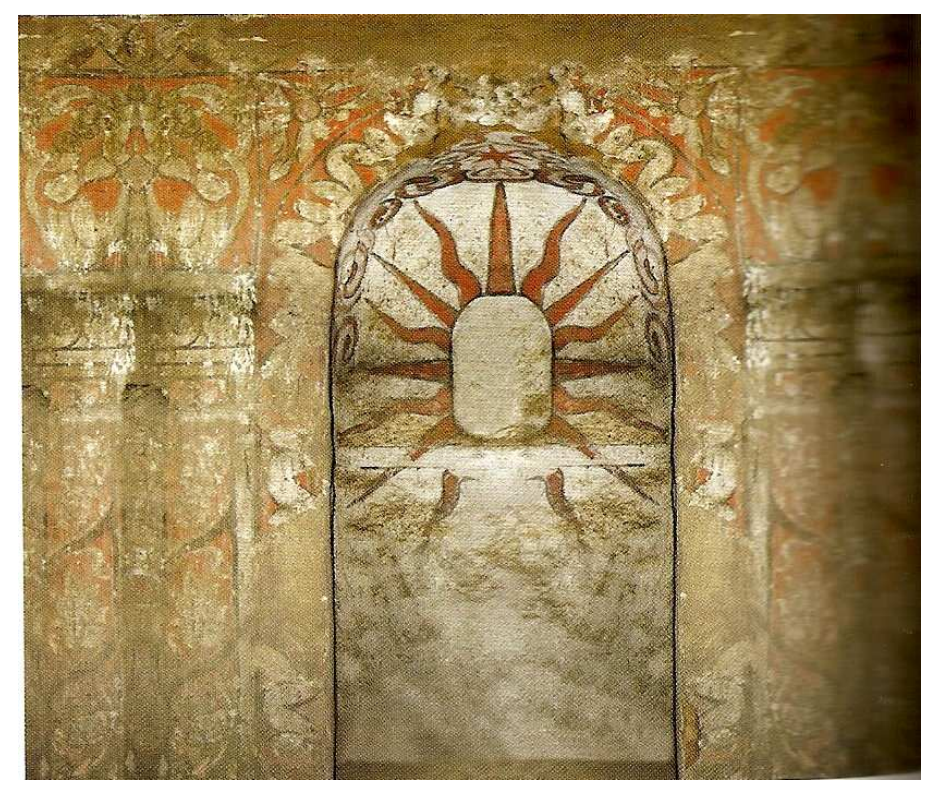

Figura 4: Pintura parietal indígena do século XVII. Foto: Victor Mori, 2007. Fonte: Carlos Lemos (2008, p. 310). 
DOSSIÊ: FONTES E PROBLEMAS COLONIAIS, LEITURAS E ANÁLISES ATUAIS:

TEMAS DA CULTURA SUL-AMERÍNDIA NO CONTEXTO COLONIAL

O interior apresenta entalhes em madeira do altar principal, do oratório e dos altares laterais que revelam o domínio da técnica indígena e formam composições originais divergentes dos modelos jesuíticos. Destacam-se duas figuras femininas talhadas em jacarandá nas extremidades da banca de comunhão que foram consideradas "como das mais antigas e autênticas expressões conhecidas da 'arte brasileira'" (COSTA, 1978, p. 63).
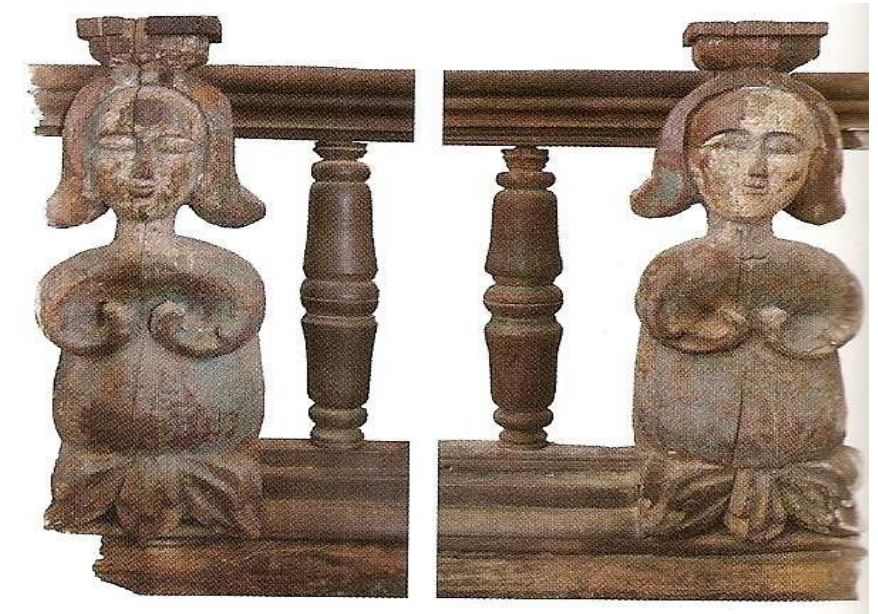

Figura 5: Figuras femininas talhadas em jacarandá. Foto de Victor Mori, 2006. Fonte: Carlos Lemos (2008, p. 308).

Na segunda metade do século XVII, muitas terras nos arredores da capela foram aforadas para os colonos. As terras do rossio, que deveriam ser de uso comum, também foram aforadas em São Paulo no período colonial, "quer pelo isolamento e distanciamento dos oficiais régios, quer pelo desconhecimento das normas legais" (GLEZER, 2007, p. 118).

Afirma Aracy Amaral que os índios e mestiços construíam capelas, mas, como se tratava de um edifício religioso, muitas vezes "não cobravam nada por seu trabalho porque a igreja era para eles. Uma vez levantada a igreja a conservação e melhoria, desde que não dissesse respeito à planta, seguia a cargo dos índios" (AMARAL, 1983, p. 74). As formas de apropriação das capelas pelos indígenas eram diversificadas e precisam ser melhor examinadas. O historiador Jean Baptista verificou 
DOSSIÊ: FONTES E PROBLEMAS COLONIAIS, LEITURAS E ANÁLISES ATUAIS: TEMAS DA CULTURA SUL-AMERÍNDIA NO CONTEXTO COLONIAL

na documentação que, nos povoados do Uruguai, no início do século XVIII, certas capelas pertenciam a caciques, onde eles rezavam "ao tempo que haviam de assistir à Igreja", cantavam e tocavam "uma caixa de guerra em cada capela, superando com isso a falta de sinos", sinalizando para a autonomia dos rituais nesses espaços religiosos (BAPTISTA, 2009, p.179).

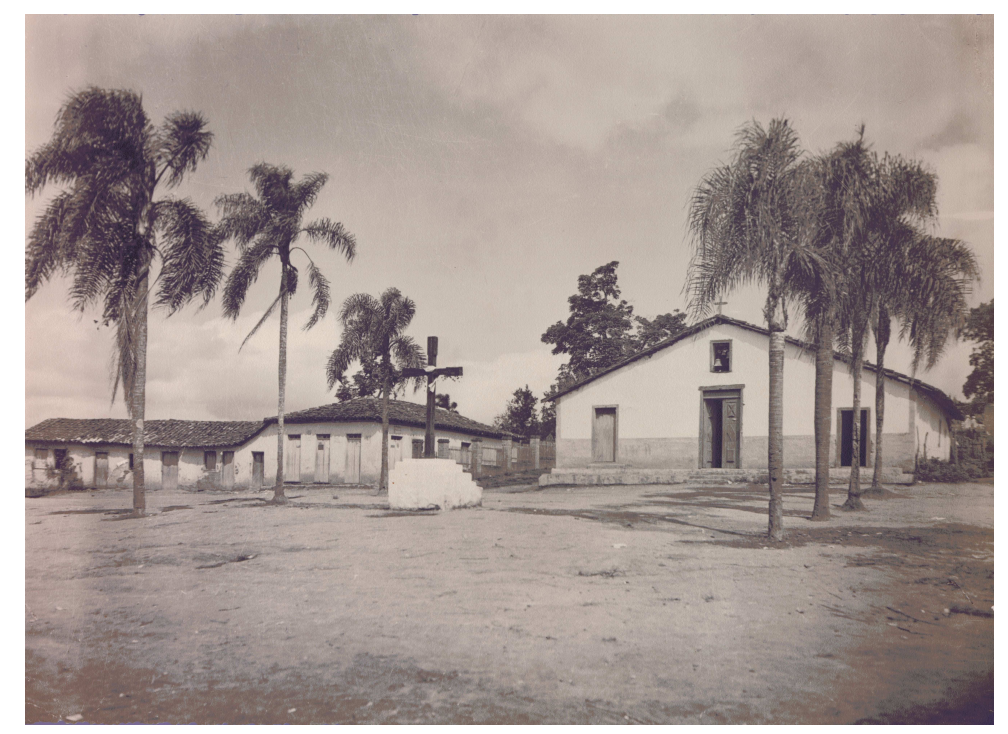

Figura 6 : Aldeia de Carapicuiba. São Paulo. Fotografia de Mário de Andrade. Acervo do Mário de Andrade no IEB/USP.

As capelas de São João, na aldeia de Carapicuiba, e a do Embu foram doadas por particulares à Companhia de Jesus no século XVII. O sertanista Afonso Sardinha ${ }^{6}$ e sua mulher, Maria Gonçalves, fizeram a doação de seus bens ao Colégio dos padres da Companhia de Jesus em 1615. A capela que havia na propriedade era a de Nossa Senhora da Graça (de Carapicuiba). Situada a poucos quilômetros da margem esquerda do Tietê, Carapicuiba ficava no caminho obrigatório do sertão de Parnaíba. Muito provavelmente, uma de suas funções era abastecer

\footnotetext{
6 "Sertanista, natural de Portugal, participou, em 1585, da expedição, por via marítima, do capitão-mor Jerônimo Leitão a Paranaguá, contra os indígenas carijós. Em S. Paulo teve patente de capitão-mor da vila em 1592. Na Câmara, exerceu as funções de vereador entre 1572 e 1610, almotacel em 1575 e juiz ordinário em 1587. Teve trapiches de açúcar em S. Paulo, na sua fazenda de Ubatatá (Butantan)" (AMARAL, 1980, p. 423).
} 
DOSSIÊ: FONTES E PROBLEMAS COLONIAIS, LEITURAS E ANÁLISES ATUAIS: TEMAS DA CULTURA SUL-AMERÍNDIA NO CONTEXTO COLONIAL

de alimentos os sertanistas. A região contou com a vizinhança de lavradores brancos e mestiços, que, além de frequentar a capela, disputavam os índios com os missionários. Os jesuítas ficaram responsáveis pela catequese e administração dos grupos indígenas descidos do sertão, sobretudo os Guarulho (Maromimim ou Guaramimi) que lá viviam. A capela atual foi feita de taipa em 1736, dedicada a São João Batista, que ainda mantém a composição original, conservando os elementos arquitetônicos do centro do aldeamento, o largo da Igreja, escola, residência e oficina, em torno do qual se alinham habitações indígenas. O terreiro foi palco de danças e representações. Uma delas é a dança de Santa Cruz, realizada anualmente em Carapicuiba, na qual Mário de Andrade identificou muitos elementos indígenas.

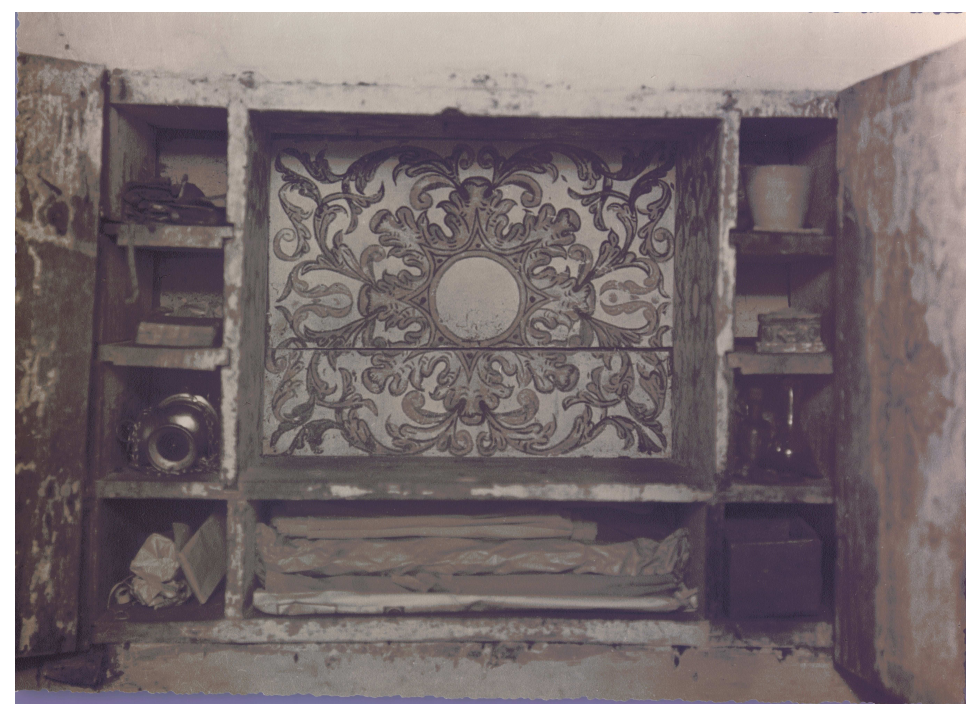

Figura 7: Armário da sacristia da Capela. Foto de Mário de Andrade. Acervo do IEB/USP.

Além das pinturas dos armários com motivos florais, semelhantes às que vimos na Capela de São Miguel, a terça da sacristia foi, certamente, decorada pelos índios. 
DOSSIÊ: FONTES E PROBLEMAS COLONIAIS, LEITURAS E ANÁLISES ATUAIS:

TEMAS DA CULTURA SUL-AMERÍNDIA NO CONTEXTO COLONIAL

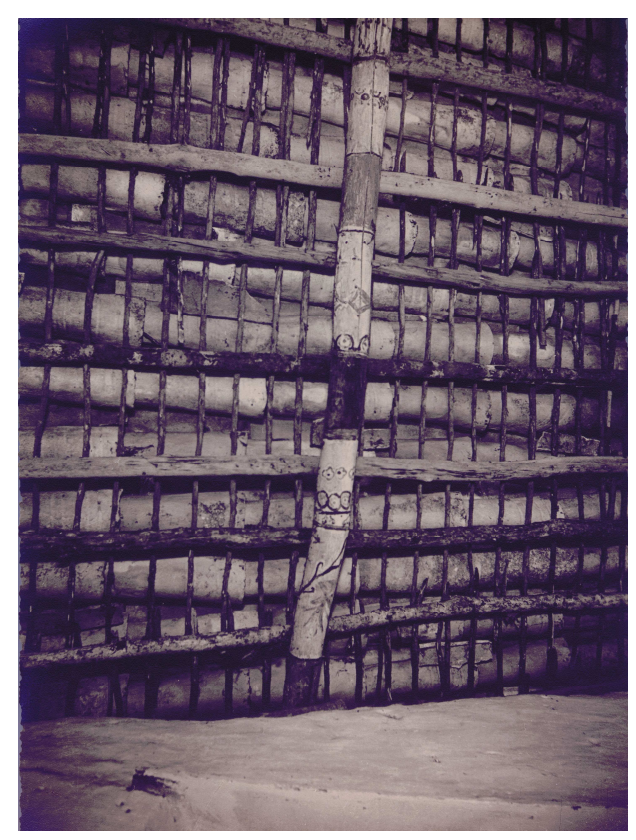

Figura 8: Terça decorada na sacristia da Capela de Carapicuiba. Fotografia de Mário de Andrade. Acervo do IEB/USP.

Com a extinção da Companhia de Jesus, Carapicuíba ficou sujeita ao vigário da paróquia de Cotia. A pobreza dos moradores da região era patente. Na última década do século XVIII, segundo informa um documento da época, a capela estava com suas paredes danificadas pelos animais, e seus oradores viviam "a mais miserável das existências". Em 1803, havia quarenta fogos e vinte e três unidades familiares que plantavam milho, feijão e algodão, das quais duas delas ainda viviam de fiar. 


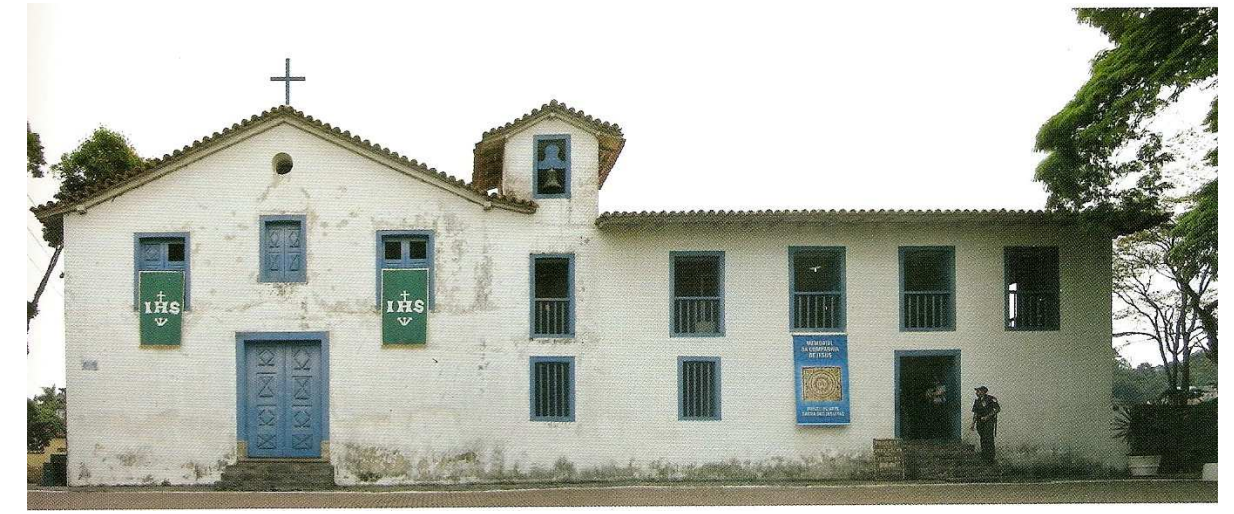

Figura 9: Igreja de Nossa Senhora do Rosário (ou M'Boy) e antiga residência jesuítica. Foto: Victor Mori, 2006. Fonte: Carlos Lemos (2008, p.111).

As terras de Fernão Dias Pais o Velho e Catarina Camacho, denominadas Boy, Bohi, Bohu, Emboi, Alboy (!), Embohu, Mboy foram doadas junto com outros bens à Companhia de Jesus em 1624. Nela havia uma capela consagrada a Nossa Senhora do Rosário. No testamento de Catarina, datado de 1655 e aprovado em 1668, ela solicita que os herdeiros conservem a igreja e que, na ocasião da festa da Senhora, se mate duas ou três reses do curral para a gente. Por volta de 1700, uma nova igreja foi erguida pelo padre Belchior de Pontes e para lá foram transferidos, segundo Serafim Leite (1953), quadros, imagens, tocheiros e o retábulo dourado da primitiva capela. Walter Zanini chama a atenção para "a pintura com os motivos chineses como pagodes e aves exóticas" que aparecem na pintura. (ZANINI, 1983, p. 138). Segundo Serafim Leite, a Aldeia de Embu exportava para o Rio de Janeiro e a Bahia pano tecido com o algodão do Brasil, "a fim de ajudar a manutenção da gente e do culto na Aldeia" (LEITE, 1953, p. 73). Neste ofício, observa o jesuíta, a intervenção dos Irmãos ou Padres era de simples superintendência, graças à aptidão dos índios.

A expulsão dos jesuítas da Capitania de São Vicente, em 1640, motivada pelos conflitos que envolveram colonos, jesuítas, a Coroa portuguesa e os grupos indígenas em torno da mão de obra e das terras, levou à desarticulação da cultura ibero-americana e à depopulação das aldeias dos arredores da vila de São Paulo. A aldeia de Pinheiros foi entregue à direção dos monges de São Bento, que 
DOSSIÊ: FONTES E PROBLEMAS COLONIAIS, LEITURAS E ANÁLISES ATUAIS: TEMAS DA CULTURA SUL-AMERÍNDIA NO CONTEXTO COLONIAL

impuseram o nome de Senhora do Monte Serrate à popular capela e empreenderam incursões com os índios aldeados a Araçariguama e a Parnaíba (AMARAL, 1969, p. 26-27). Carapicuiba ficou sujeita ao vigário da paróquia de Cotia, São Miguel passou para os religiosos franciscanos, Barueri foi transferida aos carmelitas e a Igreja de Nossa Senhora da Escada foi entregue aos capuchos ou franciscanos.

\section{Índios encapelados}

As capelas viabilizaram uma prática comum em Portugal que foi transplantada para a América portuguesa: a vinculação de bens de raiz em capelas. Muitos paulistas enriquecidos receberam licença para erguer ermidas. A concentração da população indígena chegou a níveis alarmantes, alcançando, em certas regiões, a proporção de oito índios escravos para apenas um branco. Entre 1600 e 1700, foram construídos quarenta e cinco capelas e oratórios rurais em São Paulo (MONTEIRO, 1985). A multiplicação das capelas acompanhou a formação das fazendas, o aumento das propriedades rurais, o incremento da produção agrícola e a fundação de novas vilas. O cuidado dos bens cabia aos futuros administradores da capela que não podiam "vender, nem trocar, nem escambar, nem alienar" (NIZZA DA SILVA, 2009, p. 83). Para Jorge Caldeira, os bens da capela eram considerados sagrados e os proprietários ficavam isentos de impostos, pois a produção das terras e os objetos de culto não sofriam a cobrança de dízimos, e os índios encapelados não podiam ser requisitados para o "serviço real" (CALDEIRA, 2006, p. 319). Provavelmente tratava-se de uma estratégia dos proprietários para fugir ao fisco da Coroa portuguesa. Neste caso, os objetos de culto também estavam isentos de impostos. Daí o número considerável de castiçais de prata.

Nas sesmarias do Licenciado Mateus Nunes de Siqueira e de seu irmão, Padre Jacinto Nunes de Siqueira, foi construída uma capela alpendrada, na margem direita do ribeirão Aricanduva, que abrigou a imagem de Nossa Senhora da Penha de França, por volta de 1639. A 
trajetória da devoção a Nossa Senhora da Penha de França é por si mesma reveladora das conexões do império ultramarino com a América: originária do Maciço Central da França, conhecida como Notre Dame du Puy (Nossa Senhora da Penha), foi para a Península Ibérica e suas colônias do Novo Mundo (BOMTEMPI, 1969, p. 63). Do Espírito Santo, migrou para o Rio de Janeiro, Ceará, Recife, São Paulo e Minas Gerais.

O testamento do Padre Jacinto Nunes de Siqueira, aberto em 1684 , deixou

\begin{abstract}
a Igreja com casa, em que elle viva, \& hum curral de cincoenta vacas, \& doze Índios, dos que não são senhores de toda a sua liberdade, para que conservassem aquella fazenda da Senhora. (...) Desorte que nunca faltasse á Senhora o seu culto, \& o ornato de toda aquella sua Igreja (BOMTEMPI, 1969, p. 46 e 47).
\end{abstract}

Os índios encapelados, portanto, deviam obrigações ao orago. Local de romaria e peregrinações com oferendas de "ex-votos", a capela de Nossa Senhora da Penha deu origem ao bairro da Penha.

Outro exemplo semelhante é o da capela em devoção a Nossa Senhora da Esperança, mais tarde conhecida como Nossa Senhora do Ó, erguida pelo sertanista Manoel Preto, em 1618, que legou "uma dúzia de serviços para benefício da capela e da fazenda, duas dúzias de vaca com um touro". Os bens ficariam vinculados "de hoje até o fim do mundo" (BARRO, 1977, p. 38-39). Quem administrasse a capela mandaria dizer cinquenta missas, cinco em cada ano, pela alma da casa (apud NIZZA DA SILVA, 2009, p. 83). Logo após o falecimento do proprietário, as terras da capela foram desmembradas e deram origem ao bairro de São Paulo. 


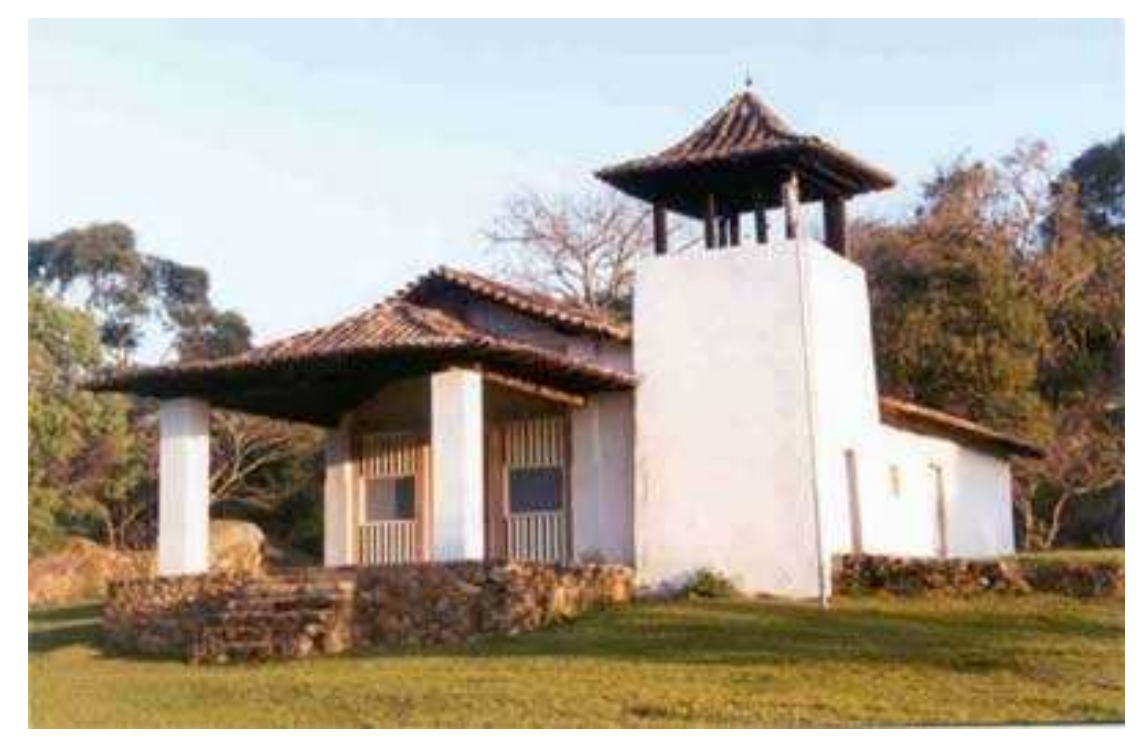

Figura 10: Capela do Sítio de Santo Antônio em São Roque, São Paulo. Doação de Mário de Andrade ao Serviço do Patrimônio Histórico e Geográfico. Foto do Acervo do IPHAN.

O capitão Fernão Paes de Barros, que alegou o grande fervor de sua segunda esposa, D. Maria de Mendonça, e a dificuldade de acesso à igreja da vila, devido à distância e ao "caminho áspero", obteve licença, em 1681, para erigir a capela de Santo Antonio, no atual município de São Roque. Além de terras, tinha "grande número de escravos do gentio da Guiné e do gentio do Brasil" (ANDRADE, 1965, p. 87). A capela esteve vinculada até 1854 . Durante esse período foram rezadas 8.650 missas pela alma do fundador (HOLANDA, 1941, p. 117). Feita de taipa, a Capela de Santo Antonio distingue-se pela influência oriental, visível pela torre fora do corpo da igreja, construída de pedra e recoberta de barro em forma de pagode. O estudo de Aracy Amaral revela que seu risco é típico de uma capela rural no Vice-Reino do Prata, e que a composição do altar é uma cópia de um modelo maneirista erudito, com influência de elementos iconográficos do altiplano peruano-boliviano, com expressões de tradição indígena.

Aracy Amaral observa também a habilidade imitativa dos Guarani para copiar modelos, recriando-os (AMARAL, 1983, p. 106). No contexto do Novo México, Gruzinski pontua que a cópia viabilizava a expressão de estilos pictóricos pré-hispânicos (GRUZINSKI, 1999, p. 222). Com relação aos índios da Amazônia, o jesuíta João Daniel ficou 
DOSSIÊ: FONTES E PROBLEMAS COLONIAIS, LEITURAS E ANÁLISES ATUAIS: TEMAS DA CULTURA SUL-AMERÍNDIA NO CONTEXTO COLONIAL

profundamente impactado com a habilidade que os índios tinham para aprender todos os ofícios e imitar os artefatos. Diz ele: "tem tal phantasia, que para imitarem qualquer artefacto basta mostrar-lhe 0 original, ou copia, e a imitam com tal magistério que ao depois faz equivocar qual seja o original, e qual a cópia" (DANIEL apud BAUMGARTEN, s/d, p. 6).

No púlpito de talha dourada, a composição da águia bicéfala, coroada, é o símbolo dos Habsburgos.

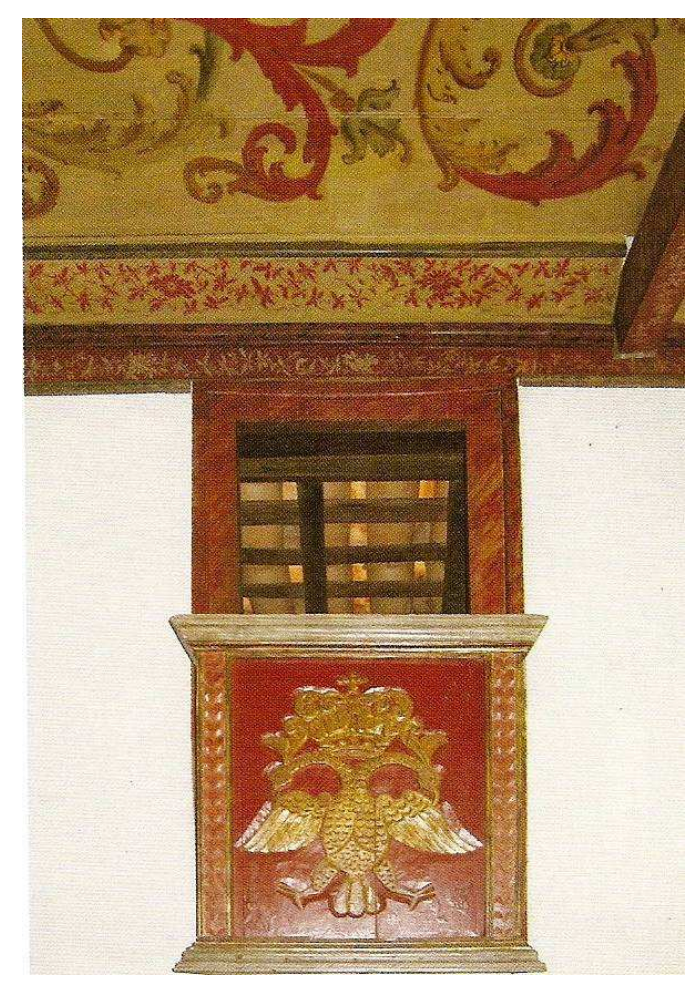

Figura 11: Púlpito com águia bicéfala, que faz parte da iconografia hispano-americana. Foto:Victor Mori. Fonte: Carlos Lemos (2008, p. 328).

A pintura ornamental do teto assemelha-se à pintura de outras capelas da região, com motivos decorativos formados por florais e arabescos. Lúcio Costa afirma que é na composição e talha dos retábulos de altar que se entrevê versões populares de modelos eruditos europeus e uma variedade de estilos do Barroco americano que conferem originalidade à obra. O modelo do retábulo de Santo Antonio, explica Mário de Andrade, é próprio dos jesuítas, com cuidadoso desenho e bela pintura, 
DOSSIÊ: FONTES E PROBLEMAS COLONIAIS, LEITURAS E ANÁLISES ATUAIS: TEMAS DA CULTURA SUL-AMERÍNDIA NO CONTEXTO COLONIAL

mas o resultado é uma "recriação" de artesãos indígenas. Em documento encontrado por Aracy Amaral, datado de 13 de outubro de 1646, de Lisboa, havia na Vila de São Paulo "mais de 40.000 índios e os mais delles carpinteiros" [...](AMARAL, 1983, p. 12).

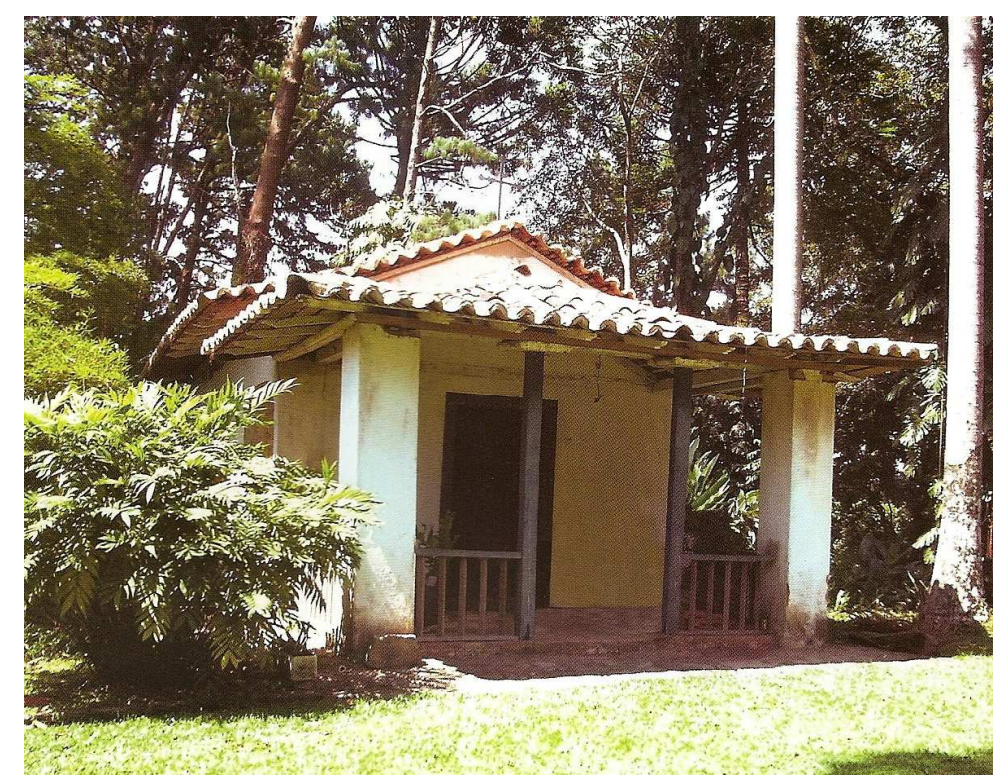

Figura 12: Capela de Nossa Senhora da Conceição (Voturuna) em 2007. Foto: Percival Tirapeli. Fonte: Carlos Lemos (2008, p. 200).

A Capela de Nossa Senhora da Conceição foi construída em 1687, em propriedade do capitão Guilherme Pompeu de Almeida no Morro de Voturuna, nas proximidades da vila de Parnaíba. Segundo Pedro Taques, seu fundador constituiu

\begin{abstract}
um copioso patrimônio em dinheiro amoedado, escravos oficiais de vários ofícios, e todos com tendas para o exercício de suas ocupações. Adornou a capela com retábulo de talha toda dourada e lhe deu ornamentos ricos para as festividades, e outros de menos custo para semanário com castiçais de prata (apud NIZZA DA SILVA, 2009, p. 83).
\end{abstract}

Entre os bens arrolados em testamento de 1710, destacam-se "204 peças de gentio da terra, 52 cabras, 100 porcos e 80 cabeças de gado" (apud NIZZA DA SILVA, 2009, p. 83). Os administradores da capela 
DOSSIÊ: FONTES E PROBLEMAS COLONIAIS, LEITURAS E ANÁLISES ATUAIS: TEMAS DA CULTURA SUL-AMERÍNDIA NO CONTEXTO COLONIAL

ficavam obrigados a mandar dizer duas missas mensais pela alma de Pompeu de Almeida com o rendimento daquele patrimônio, sobretudo com os juros do dinheiro e os escravos oficiais, que, enquanto vivessem, produziam renda para a capela.

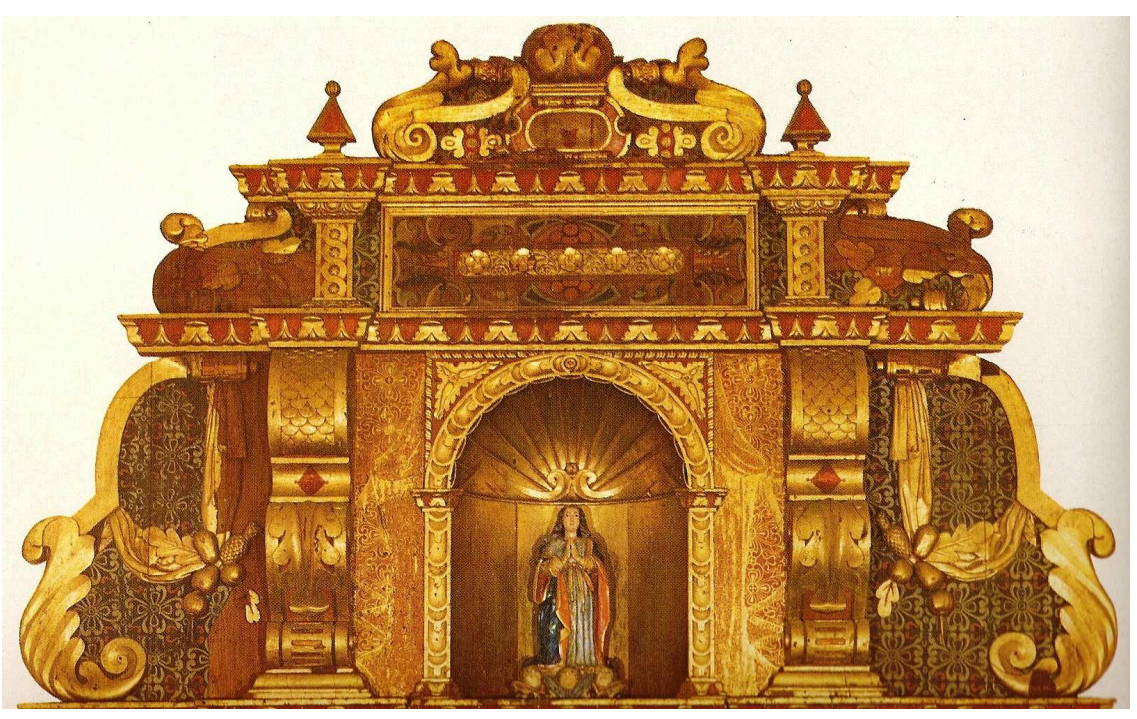

Figura 13: Retábulo da Capela de Nossa Senhora da Conceição. Observar que os cajus substituem as clássicas peras. Fonte: ARTE NO BRASIL (1980).

Mário de Andrade observa que o retábulo da capela de Voturuna é da mesma época que o de Santo Antônio, ambos originais e com alta qualidade artística. Embora tenham sido pautados em modelos maneiristas dos jesuítas, apresentam elementos originais. $O$ de Voturuna, por exemplo, representa elementos nativos, como os cajus, que sugerem a participação indígena. Para Jorge Caldeira, revela influência de artistas indígenas andinos da região de Chuquisaca, precisamente de Vila Rica do Espírito Santo, trazidos provavelmente por agentes do pai do padre Pompeu, que fazia negócios com a prata de Potosi (CALDEIRA, 2006, p. 321).

Durante o século XVII, milhares de índios despovoaram as aldeias coloniais acompanhando as correntes de expansão paulista em direção ao Vale do Paraíba, estabelecendo-se nas vilas de Mogi das Cruzes (1611), Parnaíba (1625), Taubaté (1643), Guaratinguetá (1651), Jacareí 
(1653), Jundiaí (1655), Itu (1658), Sorocaba (1661) e Curitiba (1693), enquanto outros se deslocaram para as regiões de Minas Gerais (1694), Cuiabá (1718) e Goiás (1725), para trabalhar nas minas de ouro. O movimento centrípeto da população de São Paulo, articulado ao bandeirismo, foi observado pelo historiador Sérgio Buarque de Holanda. Diz ele:

[...] despejando em periódicas pulsações as sobras de seu povo, a vila de S. Paulo se vai projetando no século XVII em novas comunidades que sucessivamente se vão formando ao largo do sertão. Se o fenômeno não tem o alcance espetacular das grandes entradas bandeirantes, o certo é que a estas se enlaça pela sua origem e serve para clareá-las de luz nova. Que ele se dava com iguais características nas comunidades secundárias ou derivadas, por sua vez erigidas em outros tantos focos de expansão, é desnecessário dizê-lo, embora seja lícito pensar que se revelasse mais sensível no núcleo primitivo e já 'saturado' do planalto (HOLANDA, 1966, p. 162-163).

$\mathrm{Na}$ maioria das vilas recém-fundadas, a população indígena superava a dos brancos. Em Sorocaba, por exemplo, a população indígena representava $83 \%$ do total (HOLANDA, 1966, p. 87). Em contrapartida, uma denúncia de meados do século XVII alertava sobre o estado das aldeias jesuíticas do Planalto Paulista (Barueri, Pinheiros, São Miguel e Guarulhos): "se acham impossibilitadas de gente por serem os índios dellas levados de moradores ao sertão, onde perecem todos, com que remontando-se nesta conformidade se vão as aldeias extinguindo [...]." (apud PETRONE, 1995, p. 185). O despovoamento das aldeias coloniais de São Paulo pode ser atribuído ao alto índice de fugas e também aos numerosos "negros da terra" que permaneceram por tempo indeterminado nas fazendas e em casas particulares, deixando os seus parentes nas aldeias da vila. É patente, no entanto, a intensa movimentação dos índios entre as aldeias, o sertão, as fazendas e as vilas. 
DOSSIÊ: FONTES E PROBLEMAS COLONIAIS, LEITURAS E ANÁLISES ATUAIS: TEMAS DA CULTURA SUL-AMERÍNDIA NO CONTEXTO COLONIAL

\section{Considerações finais}

Os índios que viveram na Capitania de São Vicente participaram ativamente da construção das capelas, da elaboração de suas técnicas e expressões. No mundo colonial, aprenderam com os irmãos e os padres jesuítas e tornaram-se os principais artífices que sustentaram o projeto missionário, produzindo obras de carpintaria, paredes de taipa, entalhes dos altares, retábulos, pinturas dos forros, nichos de sacristia, telhas e tijolos, esculturas em madeira e barro, imagens dos santos, entre tantas outras atividades essenciais à propagação da fé e à implantação do projeto missionário.

Dada a carência de mão de obra especializada na região de São Paulo, foram frequentes os processos de colonos solicitando o retorno dos índios de ofícios, acolhidos em propriedades alheias. Em 1723, a viúva Sebastiana Leite Furquim se queixou que o carijó de sua administração oficial de sapateiro, por nome Joam Sapateiro, fugiu e encontrava-se na casa de José Correa de Mesquita, e foi visto fazendo sapatos que é o seu ofício (DEP. DO ARQUIVO DO ESP, 1945, p. 12). Um outro caso curioso é o do bastardo forro Ignácio Sapateiro, que foi preso fugindo a caminho das minas do Cuiabá "por cauza de não dar conta de hum seu filho também do mesmo officio m. or no cittio do Pary" (DEP. DO ARQUIVO DO ESP, 1945, p. 145).

No início do século XVIII, a prioridade na requisição de mão de obra indígena era voltada ao descobrimento de minas de prata, ouro e esmeralda, e ao trabalho nos centros mineradores. Nas listas de população dos aldeamentos de São Paulo de 1721 a 1804, nota-se a ausência de índios adultos de ambos os sexos. Na Aldeia de N. Sra da Conceição, na década de 1720, por exemplo, 16 famílias somam um total de sessenta e quatro moradores, dos quais trinta e seis estão na aldeia, contando as crianças, e os demais dispersos e distantes. As mulheres com crianças pequenas e os homens idosos residiam nas aldeias, enquanto as jovens trabalhavam em casas particulares e os homens, nas minas, fazendas, ou tinham o paradeiro ignorado (DEP. DO ARQUIVO DO ESP, 1945, p. 49-53). Os índios das aldeias e capelas que 
DOSSIÊ: FONTES E PROBLEMAS COLONIAIS, LEITURAS E ANÁLISES ATUAIS: TEMAS DA CULTURA SUL-AMERÍNDIA NO CONTEXTO COLONIAL

permaneceram tinham a obrigação de suprir o abastecimento de São Paulo. O religioso Rafael Marques, responsável pelos cativos "encapellados", escreve, numa carta de 12 de março de 1722, que

a capella de N. S. ${ }^{\text {ra }}$ d'Ajuda contratarão com os R. ${ }^{\text {ores }}$ deste Coll. ${ }^{\circ}$, plantar o mantim. ${ }^{\text {to }}$ de q' nos sustentamos, e são nossos colonos, aq $^{m}$ pagamos o seo jornal. Dos de Mboy, e Ytapicirica nos servimos $\mathrm{p}^{\mathrm{a}}$ as conduções dos gêneros $\mathrm{q}^{\prime}$ se conduzem do mar, pagando lhes tambe o seo trabalho, e faltandonos esta conveniência não nos podemos conservar nem sustentar (DEP. DO ARQUIVO DO ESP, 1945, p. 43).

Muitas capelas ficaram nas mãos dos próprios índios, que, abandonados pelos religiosos, provavelmente se apropriaram do espaço das capelas para ressignificar suas identidades, fortalecer laços de sociabilidade e recriar ritos e cultos. Em 1732, por exemplo, na Aldeia de Nossa Senhora de Escada, o padre e visitador, o doutor Alexandre Marques do Vale, constatou que "não achou os ornam tos que o p.e bispo ordenava (...) só tem hu da cor vermelho e branco sem frontal e estar som. te em poder dos índios [...]" (VALE apud LEMOS, 2008, p. 115).

Em 1769, foi promulgada uma lei, durante o governo de D. José, que proibia que a alma pudesse ser a herdeira dos bens, ou seja, estava proibida a instituição de capelas que vinculava os bens e impunha missas e sufrágios "até o fim do mundo" (NIZZA DA SILVA, 2009, p.173).

No final do século XVIII, as aldeias de São Paulo estavam em vias de dissolução, sinalizando tanto para o fim da expansão paulista como para a falta de interesse no emprego da mão de obra indígena. A pobreza dos moradores era generalizada. Diz um documento que

um religioso capucho [que] indo a São Roque, na freguesia de Cotia, administrar os sacramentos vira lhe chegarem uns trinta ou quarenta homens, ou quiçá em número mais avultado dispondo de uma única vestia que iam envergando sucessivamente para se apresentarem ao confessionário! (DEP. DO ARQUIVO DO ESP, 1913, p. 383).

A Lista de População das aldeias coloniais do início do século XIX demonstra que, apesar da maioria dos índios trabalhar na agricultura e 
DOSSIÊ: FONTES E PROBLEMAS COLONIAIS, LEITURAS E ANÁLISES ATUAIS: TEMAS DA CULTURA SUL-AMERÍNDIA NO CONTEXTO COLONIAL

de haver um contingente considerável de índios sem terra, ainda estavam vivas as manifestações culturais indígenas. Em 1802, de acordo com o "Mapa Geral dos índios habitantes existentes na Aldeia de Pinheiros, em o presente ano", viviam 153 pessoas, das quais as mulheres de maior idade declararam ser ceramistas (louceiras) e os homens " 11 do jornal, 2 pedreiros, 1 sapateiro, 1 sacristão, achando-se fora da aldeia 18 elementos, sendo que apenas cinco com autorização" (AMARAL, 1969, p. 22). No ano de 1802, por exemplo, viviam na aldeia de Itapecirica oito músicos que formavam a banda do aldeamento. $\mathrm{Na}$ Escada, concentravam-se os louceiros, em Embu, dois carpinteiros, um pintor, uma louceira, um oficial de telhas, uma pessoa que fazia imagens, outras três obras de taquara, um mestre da capela e seis músicos. Uma ordem de 1767 solicitava

os Índios muzicos da dita Aldea, $\mathrm{q}^{\prime}$ no dia vinte $\mathrm{e}$ quatro deste corrente mez se acham na fazenda de $\mathrm{S}$. Anna termo desta Cidade, com todas as Solfas, e instrumentos que tiverem, para se festejar a Snr. ${ }^{a}$ Santa Anna desta Fazenda (apud PETRONE, 1995, p. 289).

A última informação oficial sobre o estado das aldeias de São Paulo data de 18897:

Os demais Aldeamentos - dos Pinheiros, Barueri, Carapicuhyba, S. Miguel, Itaquaquecetuba, Escada, Mboy - apenas existem in nomine. As suas terras foram invadidas por particulares e a população indígena confundida com a civilisada (VICENTE DE AZEVEDO, 1889, s./p.).

Imersos na pobreza rural do cinturão de São Paulo, os índios foram transmudados em caipiras e mestiços. À sombra da identidade caipira, porém, a capelinha devotada a um orago, com variados sinais de tradições culturais indígenas, resistiu à ação do tempo como centro da religiosidade e de sociabilidade de uma população itinerante e dispersa (CANDIDO, 2003, p. 95).

\footnotetext{
${ }^{7}$ Relatório apresentado à Assembléia Legislativa Província de São Paulo pelo presidente da província, Doutor Pedro Vicente de Azevedo, no dia 11 de janeiro de 1889.
} 
DOSSIÊ: FONTES E PROBLEMAS COLONIAIS, LEITURAS E ANÁLISES ATUAIS: TEMAS DA CULTURA SUL-AMERÍNDIA NO CONTEXTO COLONIAL

\section{Referências bibliográficas}

ACTAS da Câmara da Villa de S. Paulo. São Paulo: Archivo Municipal de S. Paulo, 1914.

ALMEIDA, Maria Regina C. de. Metamorfoses indígenas: identidades e cultura nas aldeias coloniais do Rio de Janeiro. Rio de Janeiro: Arquivo Nacional, 2001.

AMARAL Antonio B. de. O bairro de Pinheiros. São Paulo: Secretaria de Educação e Cultura da Prefeitura do Município de São Paulo, 1969.

Dicionário de História de São Paulo. São Paulo: Governo do Estado de São Paulo, 1980.

AMARAL, Aracy. A hispanidade em São Paulo: da casa rural à Capela de Santo Antonio. São Paulo: Perspectiva, 1983.

ANCHIETA, José. Cartas, informações, fragmentos históricos e sermões. Belo Horizonte/São Paulo: Itatiaia/Edusp, 1988.

ANDRADE, Mário. Aspectos das artes plásticas no Brasil. São Paulo: Livraria Martins, 1965.

A arte religiosa no Brasil: crônicas publicadas na Revista do Brasil em 1920. São Paulo: Experimento, 1993.

ARROYO, Leonardo. Igrejas de São Paulo. São Paulo: Cia. Editora Nacional, 1966.

ARTE NO BRASIL. São Paulo: Abril Cultural, 1980.

BAPTISTA, Jean. O temporal: sociedades e espaços missionais - dossiê das Missões. São Miguel das Missões: Museu das Missões, 2009. v. 1.

BARRO, Máximo. Nossa Senhora do Ó. São Paulo: Secretaria de Educação e Cultura da Prefeitura do Município de São Paulo, 1977.

BAUMGARTEN, Jens. El rol de las artes plásticas en la actividad misionera de los Jesuítas: un ejemplo en la obra de los jesuítas Johann Xaver Treyer y Johann Philipp Bettendorf en Pará y Maranhão. Não editado. s./d.

BOMTEMPI, Silvio. O bairro da Penha (Penha de França - Sesmaria de Nossa Senhora). São Paulo: Secretaria de Educação e Cultura da Prefeitura do Município de São Paulo, 1969. 
DOSSIÊ: FONTES E PROBLEMAS COLONIAIS, LEITURAS E ANÁLISES ATUAIS: TEMAS DA CULTURA SUL-AMERÍNDIA NO CONTEXTO COLONIAL

O bairro de São Miguel Paulista: a aldeia de São Miguel de Ururaí na História de São Paulo. São Paulo: Secretaria de Educação e Cultura da Prefeitura do Município de São Paulo, 1970.

BOXER, Charles R. O império colonial português. Lisboa: Setenta, 1981.

BRUNO, Ernani S. História e tradições da cidade de São Paulo. Rio de Janeiro: José Olympio, 1953. 3 v.

CALDEIRA, Jorge. O banqueiro do sertão. São Paulo: Mameluco, 2006.

CAMARGO, Paulo Florencio da S. A Igreja na História de São Paulo (1530-1624). São Paulo: Instituto Paulista de História e Arte Religiosa, 1952. 7 v.

CANDIDO, Antonio. Os parceiros do Rio Bonito: estudos sobre o caipira paulista e a transformação de seus meios de vida. 10 ed. São Paulo: Duas Cidades/Ed. 34, 2003.

CARNEIRO DA CUNHA, Manuela (Org.). História dos índios no Brasil. São Paulo: Cia. das Letras, 1992.

CARVALHO JÚNIOR, Almir Diniz. Índios cristãos: a conversão dos gentios na Amazônia Portuguesa (1653-1769). 2005. 402 f. Tese (Doutorado em História) Unicamp, [2005].

CORTESÃO, Jaime. A fundação da cidade de São Paulo: capital geográfico do Brasil. Rio de Janeiro: Livros de Portugal, 1955.

COSTA, Lucio. A Arquitetura dos Jesuítas no Brasil. In: Arquitetura Religiosa. São Paulo: USP/IPHAN, 1978.

DEPARTAMENTO DO ARQUIVO DO ESTADO. Publicação oficial de Documentos Interessantes para a História e Costumes de São Paulo. 3 ed. São Paulo: Arquivo do Estado, 1913, $94 \mathrm{v}$.

. Inventários e testamentos. São Paulo: Arquivo do Estado, 1920.

Estado, 1945.

Boletim do Departamento do Arquivo do Estado, São Paulo: Arquivo do

FONSECA, Manuel da. S. J. Vida do venerável padre Belchior de Pontes, da Companhia de Jesus da Província do Brasil. Lisboa: Officina de Francisco da Silva, 1752.

GLEZER, Raquel. Chão de terra e outros ensaios sobre São Paulo. São Paulo: Alameda, 2007. 
DOSSIÊ: FONTES E PROBLEMAS COLONIAIS, LEITURAS E ANÁLISES ATUAIS: TEMAS DA CULTURA SUL-AMERÍNDIA NO CONTEXTO COLONIAL

GRUZINSKI, Serge. La pensée métisse. Paris: Fayard, 1999.

HOLANDA, Sérgio Buarque de. Capelas antigas de São Paulo. Revista do Serviço de Patrimônio Histórico Nacional, Rio de Janeiro, v. 5, p.105-120, 1941.

Movimentos da população em São Paulo no século XVIII. Revista do Instituto de Estudos Brasileiros, São Paulo, n. 1, p. 55-111, 1966.

KOK, Glória. Os vivos e os mortos na América portuguesa: da antropofagia à água de batismo. Campinas: Editora da Unicamp, 2001.

O sertão itinerante: expedições da Capitania de São Paulo no Século XVIII. São Paulo: Hucitec/FAPESP, 2004.

LEITE, Serafim. História da Companhia de Jesus no Brasil, 1549-1760. Rio de Janeiro/Lisboa: Instituto: Nacional do Livro/Livraria Portugália, 1938-1950. 10 v.

LEITE, Serafim. Artes e ofícios dos jesuítas no Brasil (1549-1760). Lisboa/Rio de Janeiro: Livros Portugal/Brotéria, 1953.

LEMOS, Carlos (Org.). Patrimônio: 70 anos em São Paulo. São Paulo: IPHAN, 2008.

MACHADO, Alcântara. Vida e morte do bandeirante. Belo Horizonte/São Paulo: Itatiaia/Edusp, 1980.

MADRE DE DEUS, Frei Gaspar. Memórias para a História da Capitania de São Vicente. Belo Horizonte/São Paulo: Ed. Itatiaia/Edusp, 1975.

MARQUES, M. E. de Azevedo. Apontamentos históricos, geográficos, biográficos, estatísticos e noticiosos da Província de São Paulo [1876]. 3 ed. São Paulo/Belo Horizonte: Edusp/Itatiaia, 1980. 2 v.

MARTINS, Renata Maria de Almeida. Tintas da Terra, Tintas do Reino: arquitetura e arte nas Missões Jesuíticas do Grão-Pará (1653-1759). 2009. 850 f. 2 v. Tese (Doutorado em Arquitetura e Urbanismo) - Universidade de São Paulo, [2009].

MONTEIRO, John Manuel. São Paulo in the Seventeenth Century: economy and society. Illinois: University of Chicago, 1985. $2 \mathrm{v}$.

Negros da terra. índios e bandeirantes nas origens de São Paulo. São Paulo: Cia. das Letras, 1994.

Tupis, Tapuias e Historiadores: estudos de História Indígena e do Indigenismo. Campinas: Unicamp, 2001. Disponível em: http://www.ifch.unicamp.br/ihb/estudos/TupiTapuia.pdf. Acesso em: 17 mai. 2011. 
DOSSIÊ: FONTES E PROBLEMAS COLONIAIS, LEITURAS E ANÁLISES ATUAIS: TEMAS DA CULTURA SUL-AMERÍNDIA NO CONTEXTO COLONIAL

. Dos Campos de Piratininga ao Morro da Saudade: a presença indígena na história de São Paulo. In: PORTA, Paula (Org.). História da cidade de São Paulo: a cidade colonial 1554-1822. São Paulo: Paz e Terra, 2004, p. 21- 67.

NIZZA DA SILVA, Maria Beatriz (Org.). Brasil: colonização e escravidão. Rio de Janeiro: NF, 2000.

(Org.). História de São Paulo Colonial. São Paulo: Editora da Unesp, 2009.

PETRONE, Pasquale. Aldeamentos paulistas. São Paulo: Edusp, 1995.

RUIZ, Rafael. São Paulo na Monarquia Hispânica. São Paulo: IBFC "Raimundo Lúlio", 2004.

SAIA, Luis. O Alpendre nas Capelas Brasileiras. Revista do SPHAN, Rio de Janeiro, v. 3, p. 235-249, 1939.

SPALDING, Karen. The Colonial Indian: past and future research perspectives. Latin American Research Review, Austin, v. 6, n. 1, p. 47-76, 1972.

TAUNAY, Afonso de Escragnolle. História da cidade de São Paulo no século XVIII. São Paulo: Imprensa Oficial, 1931-35. 6 v.

. São Paulo nos Primeiros Anos 1554-1601: São Paulo no Século XVI. São Paulo: Paz e Terra, 2003.

TORRES, Maria Celestina T. Mendes. O bairro de Santana. São Paulo: Secretaria de Educação e Cultura da Prefeitura do Município de São Paulo, 1970.

VICENTE DE AZEVEDO, Pedro. Relatório apresentado à Assembléia Legislativa Província de São Paulo pelo presidente da província. 1889. Disponível em: http://brazil/cr.edu/bsd/1033 . Acesso em: 20 jan. 2011.

ZANINI, Walter (Org.). História Geral da Arte no Brasil. São Paulo: Inst. Moreira Salles, 1983. v. 1. 